DOSSIER

THEMATIQUE

(E)migrações, transferências, exílio: mestiçagens e dinâmicas da cidade 



\section{(E)migrações, transferências, exílio: mestiçagens e dinâmicas da cidade. Nota introdutiva}

\section{(E)migrations, transfers, exiles: crossbreeding and dynamics of the city. An introduction}

SILVIE ŠPÁNKovÁ [8346@mail.muni.cz]

Masarykova univerzita, República Checa

O presente dossier temático é constituído por uma seleção de trabalhos apresentados no colóquio internacional (E)migrações, transferências, exílio: mestiçagens e dinâmicas da cidade, organizado na Universidade Masaryk de Brno entre 16-19 de abril de 2015. O colóquio abriu espaço à reflexão de aspetos fundamentais das transferências políticas, socioculturais e outras no mundo atual, e do modo como estas são tratadas pelos pensadores, escritores e artistas em geral. O tema do colóquio atraiu vários investigadores europeus e brasileiros que, nas suas comunicações, por um lado repensaram problemáticas como migrações entre a (ex-)metrópole e suas (ex-)colónias, exílios ou estudos linguísticos do crioulo, por outro lado ofereceram novas perspetivas sobre o tópico da cidade como um pólo de atração dentro do fenónemo de transferências e, também, como um ponto de referência numa rede complexa de dicotomias, tais como aqui/lá, passado/futuro, identidade/alteridade, centro/periferia. Neste ângulo, o tema proposto do colóquio estendeu-se num leque de abordagens que permitiram estudos literários, culturais, linguísticos, filosóficos, sociólogos ou históricos. É precisamente esta variabilidade que orientou a seleção dos textos no nosso dossier.

O primeiro artigo "De uma língua oral sem escrita à escrita de uma língua oral - o caso do crioulo cabo-verdiano das Ilhas do Barlavento e Sotavento" de Natália Czopek, da Universidade de Cracóvia, abre o tema das mestiçagens através da abordagem linguística. No seu texto, a investigadora polaca descreve os traços ortográficos, morfossintáticos e lexicais do crioulo das ilhas do Barlavento e Sotavento, aproveitando para sublinhar as interferências da língua portuguesa como resultado de migrações e mestiçagem entre o povo colonizado e o colonizador.

A abordagem linguística é seguida por estudos literários que refletem, cada um privilegiando um ponto de vista, a complexa problemática das transferências físicas quase sempre acompanhadas de uma procura de identidade individual ou coletiva. Em princípio, todos os artigos da área literária que se seguem, podem ser enquadrados, em maior ou menor grau, dentro dos estudos pós-coloniais na medida em que se concentram nos temas da deslocação espacial e da estranheza daí proveniente, na problemática das atitudes híbridas, da rutura e reconfiguração de identidades, das heterotopias (cf. Seixo 2002: 502). 
O primeiro artigo na área literária abre um microbloco dedicado à obra de um dos escritores portugueses mais vocacionados para tratar os temas de migração, mestiçagem e dinâmica urbana, que é António Lobo Antunes (1942). Trata-se do estudo intitulado “Império e 'desimpério” - as questões de territorialidade em As Naus de António Lobo Antunes”, da autoria de Bálint Urbán da Universidade de Eötvös Loránd de Budapeste. Apoiando-se nas noções deleuzianas e guattarianas, o investigador húngaro desenvolve a questão da territorialidade e do espaço colonial em desconstrução que cede lugar a um espaço urbano definido pelo autor como rizomático. De facto é bem possível seguir, na história da literatura portuguesa, uma linha de reflexão que se atém ao imaginário do império, passando esta por várias fases, tal como Margarida Calafate Ribeiro demonstra no seu extenso estudo. O império como construção onírica (cf. Lourenço 1999) ou como imaginação do centro (no século XVI ou no Estado Novo) passa à ideia do império africano como não - império que, ecoando Oliveira Martins, Antero e Eça, "não representava o sentido universal atribuído por Pascoaes e Pessoa à alma portuguesa, mas antes uma imitação precária e humilhante dos impérios europeus" (Ribeiro 2004: 103), ancorando no epitáfio do império, veiculado por certa literatura pré-revolucionária e muita pós-25 de Abril. A ficção antuniana corrobora artisticamente essa desconstrução do imaginário imperial, participando com a imagem do "desimpério", desenvolvida por Bálint Urbán no seu texto.

Atenção prestada à cidade de Lisboa na obra antuniana verifica-se igualmente nos dois artigos seguintes. O primeiro, intitulado "A ficção de António Lobo Antunes: Uma legião de sons dentro do silêcio", de Evelyn Blaut Fernandes, analisa o romance O Meu Nome é Legião (2007) à base de temas de raça e violência. Como a pesquisadora brasileira bem demonstra, é precisamente neste romance que a cidade, preferencialmente nos seus aspetos suburbanos, ganha contornos de um espaço disfémico, quase fantasmático, habitado pelos espetros (outsiders adolescentes) estigmatizados pela cor de pele. Embora a distopia esteja presente igualmente na estreia de Lobo Antunes (Memória de Elefante, 1979), tendo em conta sobretudo a heterotopia do hospital psiquiátrico, podemos encontrar, neste romance, também uns indícios do mapa emocional antuniano, palimpséstico e remitificado através de referências intertextuais. É o que tento mostrar no meu artigo "Imagem da Lisboa pós-colonial em Memória de Elefante de António Lobo Antunes".

O escopo das imagens urbanas prossegue no artigo "A Manaus dos imigrantes na ficção de Milton Hatoum" de Yana Andreeva da Universidade St. Kliment Ohridski de Sofia. Neste texto, concentrado no estudo dos romances Dois irmãos e Relato de um certo Oriente de M. Hatoum, a investigadora búlgara consegue ligar todos os temas particulares do nosso colóquio: migrações, mestiçagens e dinamismo urbano, analisando o processo de reconfiguração da identidade dos imigrantes e de seus descendentes. A problemática de migrações é também desenvolvida por Zuleide Duarte em "A experiência do exílio na obra de Inácio Rebelo de Andrade". Adotando a perspetiva pós-colonial e seus instrumentos analíticos, a especialista da Universidade Estadual da Paraíba estuda, entre outros, a sensação de estranheza provocada pelo exílio no romance $\mathrm{Na}$ babugem do êxodo (2005), do autor angolano radicado em Portugal.

Os dois artigos seguintes continuam a explorar as questões migratórias. $\mathrm{O}$ trabalho de Lenka Kroupová, da Universidade Masaryk de Brno, concentra-se na análise da imagem do espaço africano no Diário de Miguel Torga, partindo sobretudo das entradas diarísticas dedicadas à viagem de Torga a Angola e Moçambique em 1973. Neste artigo, a estudiosa checa é particular- 
mente sensível às observações críticas do autor a respeito do colonialismo português em África, facto que leva a autora, numa bela imagem que dialoga com o texto de Bálint Urbán, a falar de um olhar desimperial. Prosseguindo, o estudo de Manaíra Aires Athayde, da Universidade de Coimbra, explora o problema das migrações de um ponto de vista mais interdisciplinar, baseando-se no estudo da obra Os Poucos Poderes, composta por fotografias dos anos 60, poemas dos anos 70 e somente publicada nos anos 80 do século XX. A reflexão da investigadora, porém, alarga-se ainda mais, considerando os vários fluxos migratórios portugueses na vinculação da história da literatura e da história social.

Para comprovar a riqueza das variações interdisciplinares, apresenta-se a seguir o artigo "Silêncio e pantonalidade enquanto materialidade estética em John Cage" de Caio di Palma da Universidade de Coimbra e da FCT. Este trabalho fecha o nosso dossier e, embora não diga respeito ao espaço lusófono, pode ser considerado, na sua ampliação dos temas propostos, como um convite simbólico a outras, diferentes e ricas reflexões acerca da territorialização e dinamismo urbano.

Em suma, portanto, pode constatar-se que os trabalhos apresentados neste dossier mantêm vivo o espírito da variedade, o qual era percebido como essencial na conceção do colóquio e o qual, suponho, poderá funcionar como força motriz para eventos de igual impacto no futuro.

\section{Referências bibliográficas:}

Lourenço, E. (1999). A Nau de Ícaro seguido de Imagem e Miragem de Lusofonia. Lisboa: Gradiva.

Ribeiro, M. C. (2004). Uma História de Regressos. Império, Guerra Colonial e Pós-colonialismo. Porto: Edições Afrontamento.

Seixo, M. A. (2002). Os Romances de António Lobo Antunes. Lisboa: Dom Quixote. 
